\title{
E-LEARNING TOOLS AND ICT USAGE OF OPEN AND DISTANCE EDUCATION STUDENTS
}

Mehmet FIRAT* ${ }^{*}$, Anadolu University, Open Education Faculty, Department of Distance Education

Přijato: 29. 6. 2016 / Akceptováno: 23. 8. 2016

Typ článku: Výzkumný článek

DOI: $10.5507 /$ jtie.2016.028

Abstract: The main purpose of this study was to determine the use of e-learning tools and ICTs by open and distance education students. Over than eighty thousand students from 40 different programs in the school year of 2013-2014 at Anadolu University participated to the study. A questionnaire form was developed and used as data collecting tool. According to the results of the research, open and distance students own at least one of the tools out of computer, Smart-Phone and Tablets. Almost all of the students have a Smart-Phone and internet access. It was determined that the majority of students use e-learning tools provided by the University, no matter which ICT tools they have. Internet accessibility increase the e-learning tools usage. But, remarkably high e-learning tools usage level observed also for students with limited internet accessibility. This result show that the variety and richness of provided e-learning tools have critical importance for students with limitations and disabilities to access education.

Key words: Open and distance education; e-learning tools; ICT tools

\section{VYUŽITÍ E-LEARNINGOVÝCH NÁSTROJŮ A ICT V RÁMCI OTEVŘENÉHO A DISTANČNÍHO VZDĚLÁVÁNÍ STUDENTŮ Vঙ̆}

Abstrakt: Hlavním cílem studie bylo zjistit využití e-learningových nástrojů a ICT studenty v rámci studia realizovaného formou otevreného a distančního vzdělávání. Do studie bylo zahrnuto vice než osmdesát tisic studentů ze 40 různých programi̊ realizovaných v roce 2013-14 na Anadolu University. Výsledky výzkumu vypovídaji o tom, že zkoumani studenti vlastni mimo osobního počítače alespoň jedeno z informačně-technologických zařizení. Dále bylo zjištěno, že většina studenti̊ využivá e-learningové nástroje poskytované univerzitou bez ohledu na to, jaké IT zařizení vlastní. ozoruhodnè vysoké bylo i jejich využití studenty s omezenou možností připojeni k internetu. Ukázalo se, že e-learningové nástroje maji zásadní význam pro zapojeni osob se zdravotním postižením do vzdělávání na vysokých školách.

Klíčová slova: Otevřené a distanční vzdělávání; e-learningové nástroje; ICT

*Autor pro korespondenci: mfirat@ anadolu.edu.tr 


\section{Introduction}

The trend of Information and Communication Technologies (ICT) has taken over the world with the emerging and spreading of the computers and Internet. These technologies expended to all level of society. Especially computer and internet technologies have become indispensable for different eras including education, business, science, economy, culture, transportation, law and military. The consequences of the computer and Internet emerging becoming widespread on education were quite strong and helped important innovations in the field.

Besides the obvious benefits of ICTs in education there is debate about the negative effects of the excessive use of ICT in face-to-face education (Fojtik, 2015; Comi, Gui, Origo, Pagani \& Argentin, 2016). But, in distance education technology is one of the key concepts. Without technology, implementing distance education applications is impossible. Books and correspondences took place as technological dimension in the first times of distance education applications. Although these technologies can be used in the 21 st century, communication technologies have become dominant since 20th century. There is a tendency to use cutting edge and new communication technologies in distance education. Hence, e-learning was born after some used technologies like radio and television in the applications. Moreover, e-learning is widened its borders with the development of new communication technologies. There are different application examples as m-learning, ubiquitous learning in the e-learning. Besides, some technology developments on hardware and software (including the internet) can be used in e-learning applications.

Emerging of Open and Distance Education (ODE) and widespread use of these technologies revealed the idea of equality of educational opportunity, a more democratic, independent of time and place education for all (Peters, 2003; Peters, 2009). Successful e-learning technologies provided innovative methods like MOOCs to open and distance education practices (Gooley \& Lockwood, 2012). Especially the critical role of ODE for students with limitations and disabilities has attracted the attention of the universities and governments. Because, the ODE have an important potential to close the gap between students with different limitations and opportunities for accessing learning (Geith \& Vignare, 2008). Use of ICTs and e-learning tools for students with limitations and disabilities opened the way for equal opportunities in education in a real sense. Contemporary ODE service is based on ICTs. ICT is one of the key concepts in distance education. Without ICTs, implementing distance education applications is almost impossible.

About the connectivity and technology infrastructure, notable developments have monitored especially in the Middle East and Africa, Eastern Europe and Latin America. However, compared to developed countries the gap is still at significant size. Nevertheless, some developing countries are competing with the developed countries and demonstrates better performance in some circumstances. Turkey is a good example to those countries. To the Turkish Statistic Institution, Household Information Technology Usage research, 69.5's \% of households have Internet access opportunities (TSI, 2015). These statistics are significantly above the global average $(42.3 \%)$.

In ODE systems e-learning resources have critical position. To Bates, (2005) e-learning and e-learning resources have determinative and dominant effects on ODE today. 
Therefore, pre-research, analyze, evaluation, production and re-evaluation process of e-learning resources development gain crucial importance for ODE institutions (Firat, 2014).

In related literature, e-learning is defined as learning by electronic tools and environments such as computers, internet technologies and environments or mobile devices which facilitate independent and interactive learning (Clark and Mayer, 2011). e-Learning is widened its borders with the development of new information and communication technologies (Moore and Kearsley, 2011). Thus, concepts such as lifelong learning, selfdirected learning and continuous education that occupy the current agenda of education could be said to emphasize the importance of e-learning in ODE (Bolhuis, 2003; Wilhelm and Beishuizen, 2003).

It is possible to access to descriptive studies in the related literature about the ICT ownership of ODE students (Bharuthram \& Kies, 2013; Yemisi, Owolabi, Chidinma, Kayode, Odu-Mojoyinola \& Jumoke, 2014; Fernández-Pascual, Ferrer-Cascales, ReigFerrer, Albaladejo-Blázquez \& Walker, 2015). But there are limited studies which compare the usage of e-learning tools such as interactive books, audio books, TV programs and owned ICTs. Understanding open education communication technology systems of different countries, institutions and universities gives several benefits to other universities and institutions.

The purpose of this study was to determine the use of e-learning tools and ICT by open and distance education students. In this context answers of the following questions are sought:

1. What are the ICT tools that open and distance education students have?

2. What are the Internet accessibility status of the students?

3. What are e-learning tools usage status of the students?

4. How e-learning tools usage change according to owned ICT tools and Internet accessibility?

\section{Methods}

This study is a survey research aiming to determine the use of e-learning tools and ICT by ODE students of Anadolu University. From 40 different programs, 86.842 students in the school year 2013-2014 at Open and Distance Education System, Anadolu University participated in the study. A survey was developed for data collection. In the process of developing survey form; first, drafts were formed using the literature review, drafts were presented to four field experts and were edited in the light of the feedback received. Survey form were applied to 12 students. Thus, pilot application was performed and survey was finalized. Permission was obtained from the faculty Administration for research and data collecting tool was transferred to online survey system. In this way, feedback was received from students. In this study, the quantitative data were collected and analyzed. Electronically collected data were downloaded in MS Excel format and transferred to SPSS 15 program. The data were analyzed in the SPSS 15 package program.

\section{Findings}

Obtained results were given under this title. The results were given under four subtitles according to the research questions. 
What are the ICT tools that students have? Most used ICT tools such as Smartphone, PC, TV and Tablet questioned in order to determine the usage statuses of students. Data regarding the technologies owned by 86842 students was given below in Figure 1 .

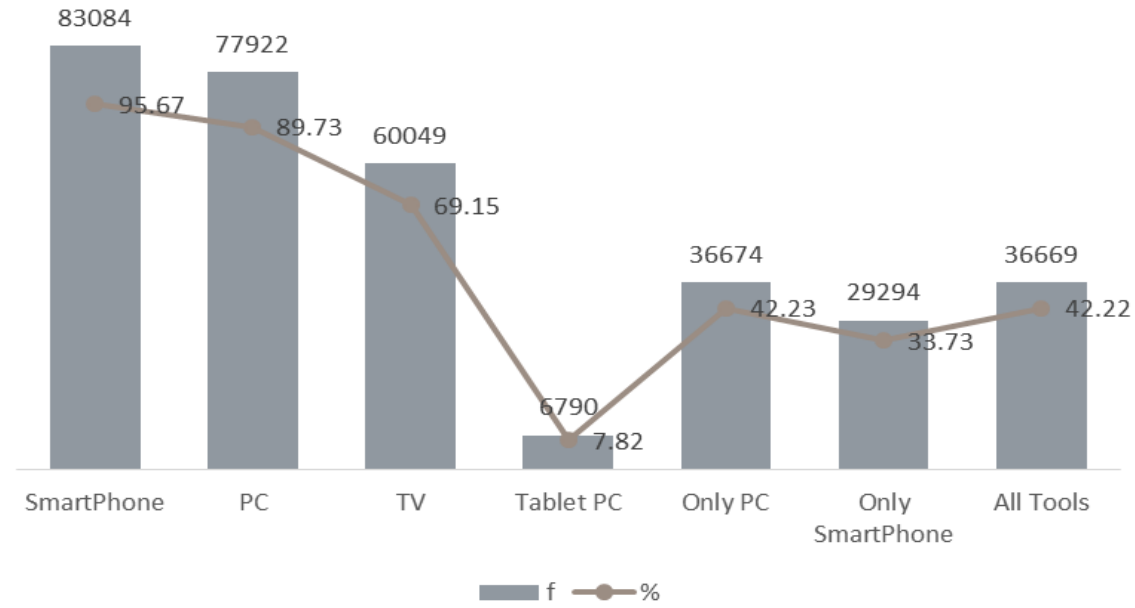

Image no. 1: ICT tools owned by ODE students

In the Figure, it can be seen that $95.67 \%$ of ODE students own a Smart-Phone and $89.73 \%$ own a PC. However, $42.23 \%$ of ODE students own only a computer, $33.73 \%$ only a Smart-Phone. $42.22 \%$ of participants own PC, Smart-Phone, TV and tablet. On the other hand, Tablet usage is observed to be low as $7.82 \%$. In general, it is determined that all ODE students own at least one of the tools out of computer, Smart-Phone and Tablet.

What is the Internet accessibility status of the students? In order to determine Internet accessibility status of the students a 5-choice question were added to the survey. Information regarding to Internet accessibility of Open Education students is summarized below in Figure 2. 


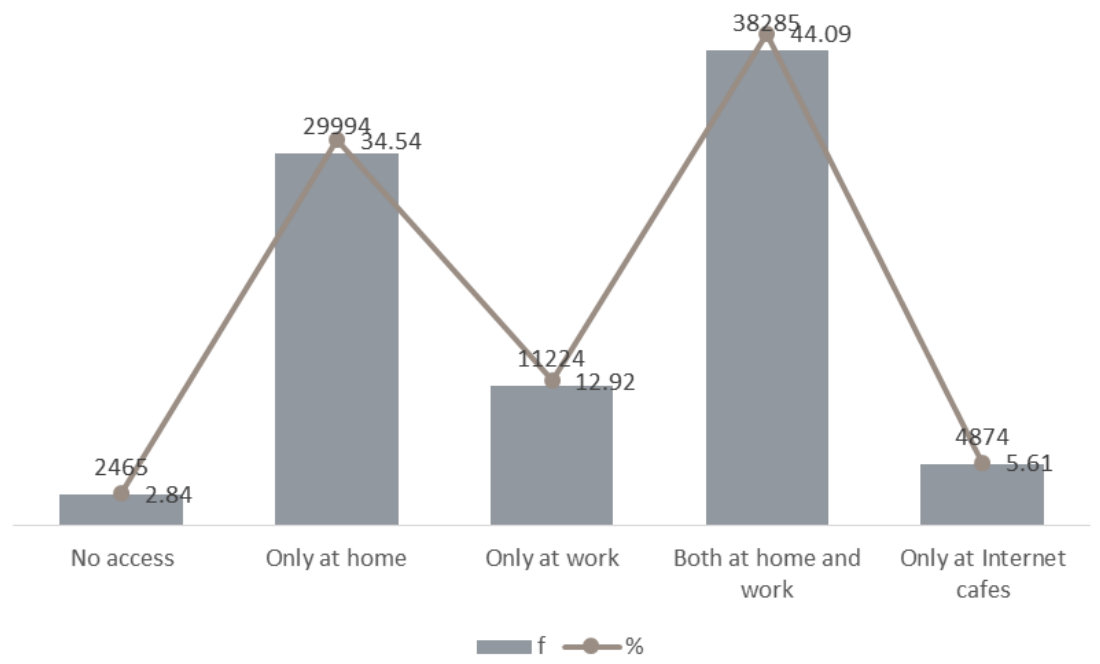

Image no. 2: Internet accessibility of students

As can be seen on the Figure 2 - internet accessibility of students have considerable differences. $44 \%$ of ODE students have internet access both at home and work, $34.54 \%$ of students have internet access only at home. This findings show that the $97 \%$ of students have Internet connection, almost half of the students have internet access both at home and at work.

What is the e-learning tools usage frequency of the students? In order to determine ODE students' usage level of e-learning tools provided by the University a 3-choice (1=rarely, 2, frequently, 3=always) question were added to the survey. Information regarding to e-learning tools usage frequency of Open Education students is summarized below in Figure 3. 


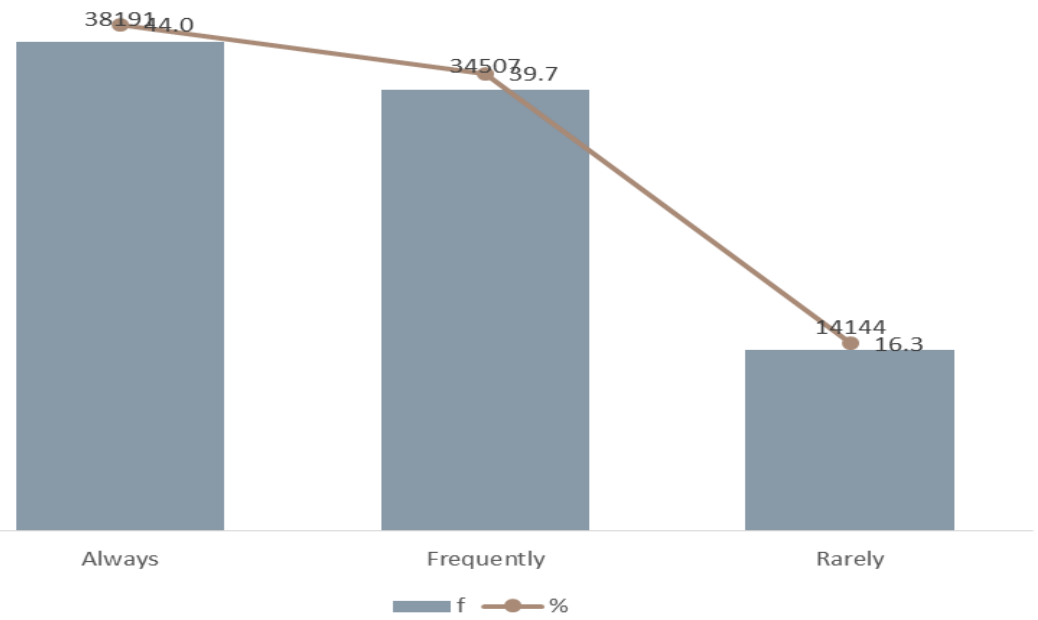

Image no. 3: E-learning tools usage levels of students

As shown in Graph 3, $44 \%$ of students "always" use e-learning tools provided by the University. Only $16 \%$ of students who participated in the study stated that they "rarely" use e-learning tools. This finding show that Anadolu University ODE students considerably $(\overline{\mathrm{X}}=2.27)$ benefit from e-learning tools provided by the University.

How e-learning tools usage frequency change according to owned ICT tools and Internet accessibility? Students' e-learning tools usage compared according to owned ICT tools. Related findings given below in Table 1.

\begin{tabular}{lc}
\hline ICT tools & e-Learning Tools Usage $(\overline{\overline{\mathbf{x}}})$ \\
\hline Smart-Phone & 2.282 \\
PC & 2.276 \\
TV & 2.287 \\
Tablet PC & 2.255 \\
All Tools & 2.260 \\
\hline
\end{tabular}

Table no. 1: E-learning tools usage levels according to owned ICT tools 
Considering that the highest e-learning tools usage level was 3 , the majority of students use e-learning tools provided by University in a high frequency $\left(\overline{\mathrm{X}}_{\text {ict }}>2.25\right)$, no matter which ICT tools they have. The obtained results show that the level of use of elearning tools don't change according to owned ICT tools. Students' e-learning tools usage levels compared also according to their internet accessibilities. Revealed findings given below in Figure 4.

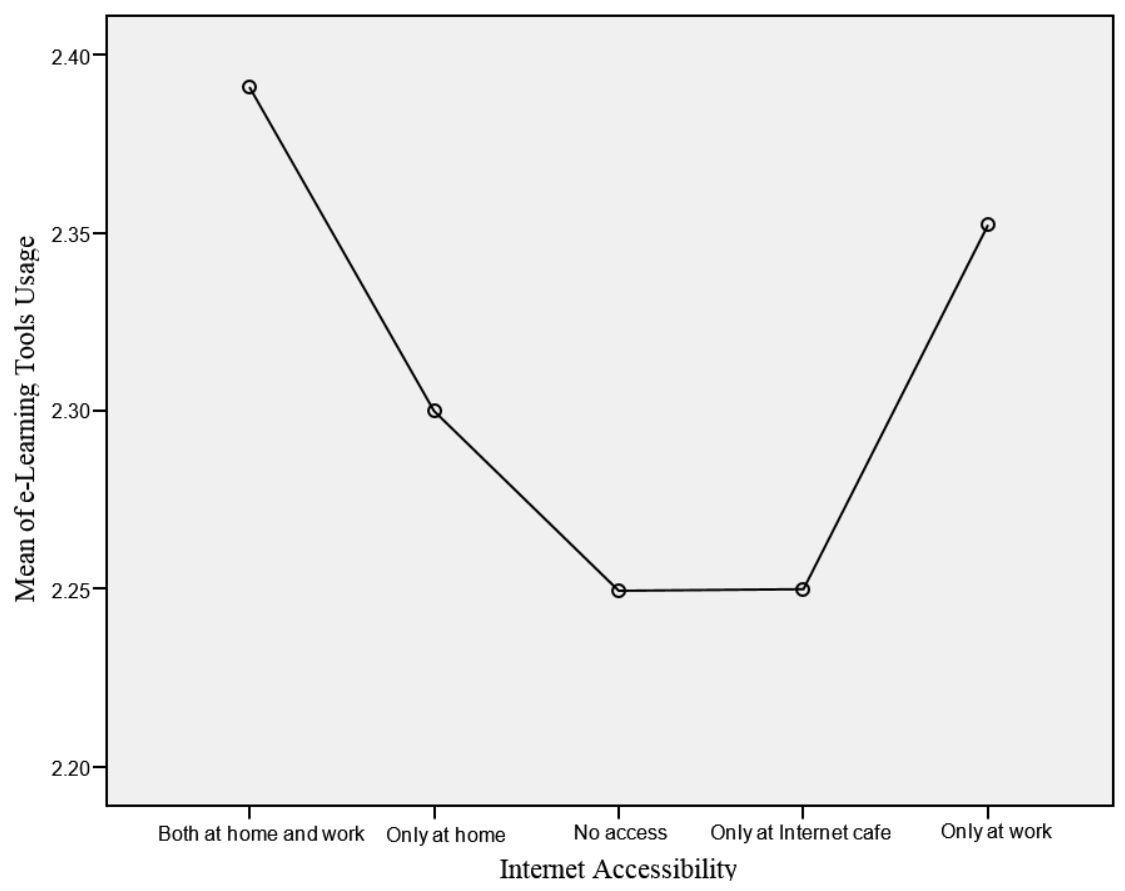

Image no. 4: E-learning tools usage levels according to internet accessibility

As can be seen in the Graph, students' e-learning tools usage means changed in the range of .15 according to internet accessibility. e-Learning tools usage of students with limited internet accessibility was about $(\overline{\mathrm{X}}=2.25)$. However, e-Learning tools usage of students with high internet accessibility (both at home and work) was higher $(\overline{\mathrm{X}}=2.40)$. These findings show that internet accessibility and e-Learning tools usage ranged in parallel. Students with limited internet accessibility also have a high level of e-learning tools usage over the average. Richness of e-learning tools provided by the university may have caused this situation. e-Learning tools such as e-books, interactive books, e-exams, e-training, e-consultation and e-audiobooks provided by Anadolu University, Open and Distance Education System can be used offline and online. 


\section{Conclusion and Suggestions}

The scope of this study is limited to Anadolu University, Open Education System students, survey as data collection tool, quantitative data and descriptive statistics. A total of 86842 students from 40 different programs of Open and Distance Education System of Anadolu University participated in the research which was conducted to determine the use of e-learning tools and ICT by ODE students. For this purpose four research questions were specified on ICT tools that students have, Internet accessibility status of the students, e-learning tools usage status of the students, e-learning tools usage change according to owned ICT tools and Internet accessibility. The data were collected by a developed questionnaire. Collected data analyzed in the SPSS package program and descriptive statistics such as percent $(\%)$, medium $(\overline{\mathrm{X}})$ and frequency $(\mathrm{f})$ were used. Some important conclusions revealed from findings.

According to the ownership of ICTs, almost all of 86842 students have a SmartPhone, one of ten students have a Tablet PC. In general, it is determined that all Open Education Faculty students own at least one of the tools out of computer, Smart-Phone and Tablets. Internet accessibility of students have considerable differences. According to the findings of the research, almost all students have internet connection, and half of the students have internet access both at home and at work. According to the findings on the use of e-learning tools, Anadolu University ODE students use e-learning tools provided by University in a high frequency, no matter which ICT tools they have. Obtained results show that the level of use of e-learning tools don't change according to owned ICT tools. These results are in compliance with Gooley and Lockwood's (2012) variety of tools and Geith and Vignare's (2008) access to education assumptions.

Students' e-learning tools usage levels were also examined in accordance with internet accessibilities. Internet accessibility and e-Learning tools usage of students ranged in parallel. Additionally, remarkably high e-learning tools usage level over the average observed also for students with limited internet accessibility. It is thought that the variety and richness of e-learning tools provided by Anadolu University, Open and Distance Education System caused this situation. Anadolu University, Open and Distance Education System provide e-learning tools such as e-books, interactive books, e-exams, e-training, e-consultation and e-audiobooks which can be used online and offline. In addition, students can watch the videos and the courses again without an internet connection on Anadolu University TRT School Channel. As a result of the analysis about the first research question, all students who participated in the study own at least one of the tools out of computer, Smart-Phone and Tablets. Students are using e-learning tools offered by the University by using these ICTs.

Based on the results obtained in this study, it is possible to suggest that ODE systems need to enrich and diversify their e-learning tools and environments in accordance with the principle of equality of educational opportunity for democratic education, lifelong and continuous education. The results showed that the variety (online and offline etc.) and richness (interactive books, audio books, TV programs etc.) of provided e-learning tools have critical importance for students with limitations and disabilities. In this way, equality of opportunity in education can be provided to citizens who struggle with geographical, economic and social limitations and especially people with disabilities. These results support Peters' $(2003 ; 2009)$ studies that underline the equality of educational opportunity effects of open and distance education. 
Future experimental and review studies can be conducted with regard to other factors of e-learning tools and ICT usage statuses of students as well as their Internet literacy. Similar researches from different universities with high numbers of participants will contribute to the literature to understand e-learning readiness of ODE students.

Acknowledgement! This study is a step of "Characteristics of Open Education Students with Trends Related to Communication and Learning Environments" entitled report studies. The abstract of the paper presented at 5th Cyprus International Conference on Educational Research.

\section{Bibliography}

Bates, A. T. (2005). Technology, e-learning and distance education. Routledge.

Bharuthram, S., \& Kies, C. (2013). Introducing e-learning in a South African Higher

Education Institution: Challenges arising from an intervention and possible responses. British Journal of Educational Technology, 44(3), 410-420.

Bolhuis S. (2003). Towards process-oriented teaching for self-directed lifelong learning: a multidimensional perspective. Learning and Instruction,13(3), 327-347.

Clark, R. C., \& Mayer, R. E. (2011). E-learning and the science of instruction: Proven guidelines for consumers and designers of multimedia learning. John Wiley \& Sons. Comi, S., Gui, M., Origo, F., Pagani, L., \& Argentin, G. (2016). Is it the way they use it? Teachers, ICT and student achievement (No. 341). University of Milano-Bicocca, Department of Economics.

Firat, M. (2014). Usage of e-Learning Resources in Open and Distance Education: Case of Anadolu University and Korean National Open University. AAOU Staff Exchange Fellowship Program: Research Paper.

Fernández-Pascual, M. D., Ferrer-Cascales, R., Reig-Ferrer, A., Albaladejo-Blázquez, N., \& Walker, S. L. (2015). Validation of a Spanish version of the Distance Education Learning Environments Survey (DELES) in Spain. Learning Environments Research, 1-18.

Fojtík, R. (2015). Comparison of Full-Time and Distance Learning Programming. Journal of Technology \& Information Education, 7(1), 35-42. DOI: 10.5507/jtie.2015.002

Gooley, A. and Lockwood, F. (Eds.). (2012). Innovation in open and distance learning:

Successful development of online and web-based learning. Routledge.

Geith, C. and Vignare, K. (2008). Access to Education with Online Learning and Open Educational Resources: Can They Close the Gap? Journal of Asynchronous Learning Networks, 12(1), 105-126.

Hakan, A., Özgür, A.Z., Toprak, E., Aydın, S. ve Firat, M. (2014). Characteristics of Open Education Students with Trends Related to Communication and Learning Environments.

Anadolu University Publication, No. 3074.

Moore, M. G., \& Kearsley, G. (2011). Distance education: A systems view of online learning. Cengage Learning.

Peters, O. (2003). Models of open and flexible learning in distance education. Planning and Management in Distance Education, 15-27.

Peters, O. (2009). The contribution of open and distance education to lifelong learning. The Routledge International Handbook of Lifelong Learning, 223.

TSI, (2015). Household Information Technology Usage Research, (Rp. No: 18660). http://tuik.gov.tr/.

Wilhelm, P. and Beishuizen, J.J. (2003). Content effects in self-directed inductive learning. Learning and Instruction, 13 (4), 381-402. 
Yemisi, O. D., Owolabi, K. A., Chidinma, A. F., Kayode, J., Odu-Mojoyinola, C., \& Jumoke, W. I. (2014). Availability and utilization of information communication technology resources for distance education students: A case study of Emmanuel Alayande College of Education, Oyo, Nigeria. Information Studies, 20(1), 5. 